\title{
PROCESO DE CARBONATACIÓN EN PASTAS DE CAL CON DISTINTA RELACIÓN AGUA/CONGLOMERANTE
}

\author{
CARBONATION PROCESS IN LIME PASTES WITH DIFFERENT \\ WATER/BINDER RATIO
}

\author{
M. ARANDIGOYEN, J. I. ÁLVAREZ(*)
}

Recepción/Received: 21-IX-05

Aceptación/Accepted: 21-XII-05

\section{RESUMEN}

La mayoría de las investigaciones sobre el proceso de carbonatación en materiales conglomerantes estudia el movimiento del frente de carbonatación. Además, los trabajos previos han sido llevados a cabo en morteros, lo que implica variaciones en el comportamiento de la carbonatación debido a la presencia del agregado. En este trabajo, la carbonatación es discutida teniendo en cuenta la variación del peso como consecuencia de la absorción de $\mathrm{CO}_{z}$ al establecer un nuevo parámetro $A$ (independiente del proceso de secado). Este parámetro ha sido evaluado en varias pastas de cal con distinta relación $A / C$ (agua/conglomerante), y su variación se ha correlacionado con la microestructura de las pastas. Durante el proceso de la carbonatación, y debido al tipo de porosidad de las pastas de cal, tiene lugar la difusión de Fick: el agua no es retenida por capilaridad sino por adsorción sobre la superficie. El proceso de secado no retrasa la carbonatación en las pastas de cal.

Palabras clave: cinética, microestructura, carbonatación, pastas de cal.

\section{INTRODUCCIÓN}

Un gran número de estudios previos (1-5) sobre la carbonatación de materiales conglomerantes están basados en la evaluación del espesor de carbonatación como dato experimental. La variación del peso registrada puede ser consecuencia de la intrusión y reacción del $\mathrm{CO}_{2}$ como de la pérdida de agua. La variación de masa permite evaluar la cantidad de $\mathrm{Ca}(\mathrm{OH})_{2}$ que reacciona en cada momento, ecuación [1]:

$$
\mathrm{Ca}(\mathrm{OH})_{2}+\mathrm{CO}_{2} \leftrightarrow \mathrm{CaCO}_{3}+\mathrm{H}_{2} \mathrm{O}
$$

(*)Departamento de Química. Universidad de Navarra, Navarra (ESPAÑA). Persona de contacto/Corresponding author. jalvarez@unav.es (J. I. Álvarez).

Most research on binder carbonation is based on the analysis of depth changes in the carbonation front. Moreover, previous studies have dealt with mortars, where aggregates play a role in the variations in carbonation patterns. In the approach adopted in the present study, carbonation was determined in terms of the variation in weight resulting from $\mathrm{CO}_{2}$ absorption, and a new parameter (independent of the drying process), denominated $A$, was established. This parameter was assessed in several lime pastes with different $W / B$ (water/binder) ratios and its variations were correlated to paste microstructure. Due to the type of porosity prevailing in lime pastes, diffusion took place according to Fick's law; water was retained not by capillarity but by surface adsorption. Drying did not retard carbonation in lime pastes

Keywords: kinetics, microstructure, carbonation, blended pastes.

\section{INTRODUCTION}

A fair number of prior studies (1-5)on the carbonation of binding materials have been based on evaluating experimental findings on carbonation depth. However, since the variation recorded in specimen weight may be the result of both $\mathrm{CO}_{2}$ penetration / reaction and water loss, variations in mass can be used to assess the amount of $\mathrm{Ca}(\mathrm{OH})_{2}$ reacting at any given time, eq.[1]: 
Un gran número de publicaciones se centran sobre el tema de la carbonatación de la cal en polvo (6-8), y otras en la carbonatación de morteros de cal (4, 9-12). La mayoría de los autores estudian este proceso evaluando el avance del frente de carbonatación. El estudio de la carbonatación en morteros de cal lleva consigo algunas modificaciones del comportamiento debido a la presencia del agregado, ya que éste da lugar a cambios en la estructura porosa. La importancia y las consecuencias de la carbonatación de la cal hidratada son bien conocidas (5): la cal hidratada ha sido ampliamente usada en seco y en procesos de eliminación de gases sulfurados mediante pulverización en seco (7), también en la tecnología de la construcción, porque el $\mathrm{Ca}(\mathrm{OH})_{2}$ aparece en morteros de cal y de cemento, y su carbonatación está fuertemente ligada a la resistencia mecánica de estos materiales (13).

El conocimiento sobre la cinética del proceso de la carbonatación es muy importante en materiales conglomerantes de cal (12) para establecer el tiempo en el que estos materiales exhiben resistencias mecánicas. Además, la absorción de algunas sustancias en la cal, tales como $\mathrm{SO}_{2}$, tiene el mismo comportamiento que la absorción del $\mathrm{CO}_{2}$.

El propósito de este trabajo es proponer, en pastas de cal, un método para evaluar el proceso de la carbonatación basado en la variación del peso, evitando las alteraciones debidas a la presencia del agregado y a los problemas asociados a la evaluación del frente de carbonatación, como son: i) la ausencia de homogeneidad en el frente de carbonatación (es decir, las irregularidades en el avance según las zonas); ii) la amplia interfase que separa la parte carbonatada y la no carbonatada, que dificulta el establecimiento de la línea de carbonatación $(3,4)$.

Este trabajo pretende también investigar la influencia del secado en el proceso de curado: es importante establecer si esta etapa retrasa el proceso de carbonatación debido al bloqueo de los poros por el agua (10), y si es así, en qué medida lo hace.

\section{EL PROCESO DE CARBONATACIÓN}

Durante la carbonatación el $\mathrm{Ca}(\mathrm{OH})_{2}$ reacciona con el $\mathrm{CO}_{2}$ formando $\mathrm{CaCO}_{3}$. El carbonato cálcico formado mejora la resistencia debido a la modificación microestructural. La ecuación [1], que es considerada irreversible, es la descripción más simple de las diversas etapas que integran este proceso (14):

1) Difusión del $\mathrm{CO}_{2}$ a través del mortero

2) Disolución del $\mathrm{CO}_{2}$ en el agua de los poros (ley de Henry)

3) Equilibrio químico del $\mathrm{CO}_{2}$ en agua

4) Disolución del $\mathrm{Ca}(\mathrm{OH})_{2}$

5) Precipitación del $\mathrm{CaCO}_{3}$

6) Desorción del $\mathrm{H}_{2} \mathrm{O}$

1.- Como una primera aproximación, la difusión del $\mathrm{CO}_{2}$ a través de la estructura porosa aparece como una de las etapas más importantes de este proceso porque puede ser el factor limitante $(5,10,11)$. Esta difusión está fuertemente influenciada por la microestructura del mortero: el
Many papers have focused on carbonation in lime powder (6-8) and others on carbonation in lime mortars (4, 912). Most authors have studied this process by analyzing the changes in the depth of the carbonation front. When studying carbonation in lime mortars, allowance must be made for certain modifications in behaviour due to the presence of the aggregate, which gives rise to changes in the pore structure. The importance and consequences of hydrated lime carbonation are well known (5); dry hydrated lime powder has been widely used, and lime spray dryers are commonly employed to eliminate sulphide gases (7); the process is also important in construction technology, for the carbonation of the $\mathrm{Ca}(\mathrm{OH})_{2}$ appearing in lime and cement mortars is closely related to the mechanical strength of these materials (13).

An understanding of carbonation kinetics in lime-based binders (12) is instrumental to establishing the time it takes for these materials to exhibit mechanical strength. Moreover, lime absorption of certain substances such as $\mathrm{SO}_{2}$ follows the same pattern of behaviour as the absorption of $\mathrm{CO}_{2}$.

The purpose of the present study is to propose a method for evaluating carbonation in lime pastes based on variations in weight, to obviate aggregate-related alterations and the problems associated with evaluating the carbonation front, such as: front irregularities (i.e., different penetration depths in different zones) and the wide interface between the carbonated and noncarbonated areas, which makes it difficult to establish the carbonation line $(3,4)$.

This paper also explores the effect of drying on the curing process to determine whether carbonation is retarded by the obstruction of the pores by water before drying is completed (10) and if so, to what extent.

\section{CARBONATION}

In carbonation, $\mathrm{Ca}(\mathrm{OH})_{2}$ reacts with $\mathrm{CO}_{2}$ to form $\mathrm{CaCO}_{3}$. The calcium carbonate formed increases strength due to microstructural changes. Eq. [1], generally regarded to be irreversible, is the simplest description of the various stages comprising this process (14):

1) $\mathrm{CO}_{2}$ diffusion through the mortar

2) Dissolution of the $\mathrm{CO}_{2}$ in the water held in the pores (Henry's law)

3) Chemical equilibrium of the $\mathrm{CO}_{2}$ in water

4) Dissolution of the $\mathrm{Ca}(\mathrm{OH})_{2}$

5) Precipitation of $\mathrm{CaCO}_{3}$

6) $\mathrm{H}_{2} \mathrm{O}$ desorption

1.- $\mathrm{CO}_{2}$ diffusion through the porous structure appears to be one of the most important stages in this process because it can be a limiting factor $(5,10,11)$. Such diffusion is closely related to mortar microstructure: the type of diffusion that takes place - surface, Fick's or Knudsen 
tipo de difusión que tiene lugar es en función del diámetro de poro y del recorrido medio libre de las moléculas que difunden, pudiendo ser: difusión superficial, de Fick o de Knudsen.

La difusión de Fick tiene lugar si el diámetro de poro es mayor que el recorrido medio libre. En este caso, las moléculas colisionan varias veces entre ellas antes de colisionar con las paredes de los poros. La difusión de Knudsen tiene lugar si el diámetro de poro es menor que el recorrido medio libre. Aquí las moléculas colisionan varias veces con las paredes de los poros antes de colisionar con otra molécula. En este último caso, la difusión está muy influenciada por la microestructura, y es importante tanto el tamaño de poro como la complejidad de la distribución de tamaño de poro del mortero (15).

2.- Cuando el $\mathrm{CO}_{2}$ atmosférico llega adentro del mortero, se establece un equilibrio entre el $\mathrm{CO}_{2}$ atmosférico y el $\mathrm{CO}_{2}$ disuelto en agua (condensado por capilaridad o adsorbido en la superficie). La ley de Henry, ecuación [2], determina este equilibrio. Para este proceso, la cantidad de agua en el interior del mortero es muy importante. El contenido en agua del mortero está relacionado con la humedad ambiental. En un mortero saturado en agua, la difusión del $\mathrm{CO}_{2}$ a través de la estructura ( $y$, consecuentemente, la carbonatación) está impedida, aunque en ausencia de agua la disolución del $\mathrm{CO}_{2}$ no tiene lugar, por tanto la carbonatación tampoco ocurre, o bien lo hace de una forma muy lenta (10). Este proceso puede ser interpretado como una reacción de Eley-Rideal en la cual una molécula $\left(\mathrm{CO}_{2}\right)$ difunde hasta su reacción con otra que está adsorbida $\left(\mathrm{H}_{2} \mathrm{O}\right)(16)$. diffusion -depends on pore diameter and the mean free path of the flowing molecules.

Fick's law holds when the pore diameter is greater than the mean free path. In this case, molecules collide with other molecules several times before impacting pore walls. Knudsen diffusion takes place if the pore diameter is smaller than the mean free path. Here each molecule collides several times with pore walls before colliding with other molecules. In the latter case, diffusion is greatly affected by microstructure, in which both pore size and the complexity of the pore size distribution are key factors (15).

2. - When atmospheric $\mathrm{CO}_{2}$ penetrates inside the mortar, an equilibrium is reached between atmospheric $\mathrm{CO}_{2}$ and the $\mathrm{CO}_{2}$ dissolved in the water (capillarity condensation or surface adsorption). This equilibrium is governed by Henry's law, eq. [2]. The amount of water inside the mortar is very important to this process. And mortar water content is related, in turn, to environmental humidity. $\mathrm{CO}_{2}$ diffusion across the structure (and consequently, carbonation) is obstructed in waterlogged mortar. However, since $\mathrm{CO}_{2}$ cannot dissolve in the absence of water, carbonation does not take place under such circumstances either, or it does so very slowly (10). This process may be viewed in the context of the Eley-Rideal mechanism, where an incoming molecule $\left(\mathrm{CO}_{2}\right)$ flows freely until it reacts with an adsorbed molecule $\left(\mathrm{H}_{2} \mathrm{O}\right)(16)$.

$$
\left[\mathrm{CO}_{2}\right]=\mathrm{K}_{\mathrm{H}} \cdot \mathrm{P}_{\mathrm{CO}_{2}}
$$

3.- El equilibrio químico se alcanza según la ecuación [3]: el $\mathrm{CO}_{2}$ en disolución reacciona con el agua y forma ácido carbónico.
3. - Chemical equilibrium is reached as depicted in eq. [3]: the dissolved $\mathrm{CO}_{2}$ reacts with water to form carbonic acid.

$$
\mathrm{CO}_{2}+\mathrm{H}_{2} \mathrm{O} \leftrightarrow \mathrm{H}_{2} \mathrm{CO}_{3} \leftrightarrow \mathrm{H}^{+}+\mathrm{HCO}_{3}^{-} \leftrightarrow 2 \mathrm{H}^{+}+\mathrm{CO}_{3}^{2-}
$$

4.- La disolución del hidróxido de calcio puede ser descrita por la ecuación [4]. Esta reacción está influenciada por la cantidad de agua y por la microestructura del mortero (4).
4. - Calcium hydroxide dissolution may be described as in eq. [4]. This reaction is affected by the amount of water available and mortar microstructure (4).

$$
\mathrm{Ca}(\mathrm{OH})_{2} \leftrightarrow \mathrm{Ca}^{2+}+2 \mathrm{OH}^{-}
$$

5.- Finalmente, la disolución al contener iones calcio e iones carbonato da lugar a la precipitación de carbonato cálcico formando pequeños cristales de calcita, de acuerdo a la ecuación [5].

$$
\mathrm{Ca}^{2+}+\mathrm{CO}_{3}^{2-} \leftrightarrow \mathrm{CaCO}_{3}
$$

6.- Puede describirse un equilibrio entre el contenido en agua del mortero y la humedad relativa del ambiente, teniendo en cuenta que el agua es un producto final de la reacción, ecuación [1].
5. - Finally, since the solution contains calcium and carbonate ions, calcium carbonate precipitates, forming small calcite crystals as in eq. [5].

6. - An equilibrium may be defined between the water content in the mortar and the relative humidity, bearing in mind that water is the final reaction product, eq. [1]. 
Todo el proceso de carbonatación, en conjunto, puede ser explicado a través de un balance de materia para el dióxido de carbono asumiendo un estado estacionario, ecuación [6] (17):
The carbonation process as a whole can be explained in terms of a matter balance for carbon dioxide, assuming the existence of a steady state, eq. [6)] (17):

$$
\frac{d}{d t}\left\{P_{a} \cdot\left[(1-S) \cdot \rho_{g}+S \cdot \rho_{d}\right]\right\}+\operatorname{div} J_{\mathrm{CO}_{2}}-Q_{\mathrm{CO}_{2}}=0
$$

donde $\mathrm{P}_{\mathrm{a}}$ es la porosidad, $\mathrm{S}$ es la saturación con agua del sistema poroso, $\rho_{g}$ es la densidad del dióxido de carbono gas $\left(\mathrm{kg} / \mathrm{m}^{3}\right), \rho_{d}$ es la densidad del dióxido de carbono disuelto $\left(\mathrm{kg} / \mathrm{m}^{3}\right), J_{\mathrm{CO}_{2}}$ es el flujo total de dióxido de carbono gas y disuelto $\left(\mathrm{kg} / \mathrm{m}^{2} \cdot \mathrm{s}\right)$, y $Q_{\mathrm{CO}_{2}}$ es la reacción química, que está en función del contenido en agua y de la concentración de $\mathrm{CO}_{2}$.

El primer término de la ecuación, representado por la ley de Henry [2], evidencia la importancia del contenido en agua durante el proceso de carbonatación. Además, la reacción tiene lugar en medio acuoso, y puede modificar el coeficiente de difusión del material por obstrucción de los poros. El segundo término hace alusión a la difusión del $\mathrm{CO}_{2}$ que tiene especial importancia en cementos y cales porque es el proceso que controla la velocidad de reacción. Si predomina la difusión de Fick, se pueden aplicar ecuaciones lineales. Si sólo tiene lugar la difusión de Knudsen, se deberán aplicar ecuaciones no lineales para tener en cuenta la tortuosidad y conectividad de los poros del sistema (teoría de la percolación) (16). El tercer término se refiere a la reacción que está muy bien estudiada en cal en polvo, determinando la disolución de $\mathrm{CO}_{2}$ en agua como el factor determinante de la velocidad de reacción $(7,9)$.

\section{EXPERIMENTAL}

\subsection{Preparación de las pastas}

42 probetas prismáticas de $40 \times 40 \times 160 \mathrm{~mm}$ fueron elaboradas con una cal comercial en polvo hidratada (Ecobat $\left.{ }^{\circledR}\right)$, cuya caracterización aparece en un trabajo previo (18), y mezclada con diferentes cantidades de agua de amasado para obtener seis relaciones diferentes $A / C$ (agua/conglomerante) $(0,8 ; 0,9 ; 1,0 ; 1,1 ; 1,2$ y 1,3$)$.

La Tabla 1 presenta el análisis químico de la cal utilizada. Los análisis de TG-ATD y DRX fueron llevados a cabo en la investigación previamente citada, mostrando dos fases mineralógicas: portlandita ( $87 \%$ ) y calcita $(10 \%)$, con un $3 \%$ de agua. No se encontró ningún compuesto de magnesio ( $\mathrm{MgO}, \mathrm{Mg}(\mathrm{OH})_{2}$, dolomita o magnesita), que tienen una carbonatación más lenta.

Las pastas se mezclaron durante 5 minutos en un mezcladora Proeti ETI 26.0072, incluidas en moldes prismáticos, y desmoldadas al cabo de 3 días. Las probetas se curaron en posición vertical y en condiciones de laboratorio (HR 60 $\pm 10 \%$ y $20 \pm 5{ }^{\circ} \mathrm{C}$ ). La concentración de $\mathrm{CO}_{2}$ en la habitación se estimó aproximadamente la concentración atmosférica estándar $(0,033 \pm 0,001 \%$ en volumen). Tres días después, las caras de $40 \times 40 \mathrm{~mm}$ fueron cubiertas
Where $P_{a}$ is porosity, $S$ is the water saturation of the porous system, $\rho_{g}$ is the density of carbon dioxide gas $\left(\mathrm{kg} / \mathrm{m}^{3}\right), \rho_{d}$ is the density of dissolved carbon dioxide $\left(\mathrm{kg} / \mathrm{m}^{3}\right), J_{\mathrm{CO}}$ is the total flow of gaseous and dissolved carbon dioxide, and $Q_{\mathrm{CO}_{2}}$ is the chemical reaction, which depends on water content and $\mathrm{CO}_{2}$ concentration.

The first term of the equation, represented by Henry's law [2], provides support for the importance of the water content during carbonation. Moreover, the reaction takes place in water, while water may in turn affect diffusion by obstructing the pores. The second term alludes to $\mathrm{CO}_{2}$ diffusion, which is of particular importance in cement and lime because it is the process that controls the reaction rate. Where Fick's diffusion prevails, linear equations may be used. Where only Knudsen diffusion is present, non-linear equations must be applied to take the intricacy and connectivity of the system pores into consideration (percolation theory) (16). The third term refers to the reaction, broadly studied in powdered lime, that establishes that $\mathrm{CO}_{2}$ dissolution in water is the determining factor in the reaction rate $(7,9)$.

\section{EXPERIMENTAL}

\subsection{Paste preparation}

Forty two $42 \times 40 \times 160 \mathrm{~mm}$ specimens were made with a commercial hydrated lime powder (Ecobat ${ }^{\circledR}$ ) whose properties are described in a previous paper (18), mixed with varying amounts of water to obtain six different $W / B$ (water/binder) ratios (0.8, 0.9, 1.0, 1.1, 1.2 and 1.3).

The chemical composition of the lime used is given in Table 1. According to the TG-DTA and XRD analyses conducted in that previous study, the lime contains two mineralogical phases: portlandite (87\%) and calcite (10\%), and 3\% water. No magnesium compound (MgO, $\mathrm{Mg}(\mathrm{OH})_{2}$, dolomite or magnesite) with slower carbonation rates was found.

After mixing for 5 minutes in a Proeti ETI 260072 mixer, the pastes were poured into prismatic moulds, from which they were removed 3 days later. The specimens were cured in a vertical position under laboratory conditions ( $R H$ H $60 \pm 10 \%$ and $T 20 \pm 5^{\circ} \mathrm{C}$ ). The indoor $\mathrm{CO}_{2}$ content was estimated to be approximately equal to standard atmospheric concentration (0.033 \pm $0.001 \%$ by volume). Three days later, the $40 \times 40 \mathrm{~mm}$ 
TABLA $1 /$ TABLE 1

Análisis químico de los principales componentes de la cal comercial en polvo hidratada (Ecobat $\left.{ }^{a}\right)^{a, b}$

Chemical analysis of the main components of the hydrated commercial lime powder (Ecobat $)^{a, b}$

\begin{tabular}{|c|c|c|c|c|c|c|c|c|}
\hline & $\begin{array}{c}\mathrm{P} . \mathrm{C}^{\mathrm{C}} \\
(\%)\end{array}$ & $\begin{array}{c}\mathrm{SiO}_{2} \\
(\%)\end{array}$ & $\begin{array}{c}\mathrm{CaO} \\
(\%)\end{array}$ & $\begin{array}{c}\mathrm{MgO} \\
(\%)\end{array}$ & $\begin{array}{c}\mathrm{R}_{2} \mathrm{O}_{3}{ }^{\mathrm{d}} \\
(\%)\end{array}$ & $\begin{array}{c}\mathrm{SO}_{3} \\
(\%)\end{array}$ & $\begin{array}{c}\mathrm{Na}_{2} \mathrm{O} \\
(\%)\end{array}$ & $\begin{array}{c}\mathrm{K}_{2} \mathrm{O} \\
(\%)\end{array}$ \\
\hline $\mathrm{Cal} /$ Lime & 25.25 & 1.03 & 68.53 & 3.29 & 0.89 & 1.37 & 0.09 & 0.05 \\
\hline D.E. $^{*}$ & 1.20 & 0.10 & 1.10 & 0.42 & 0.11 & 0.22 & 0.02 & 0.03 \\
\hline
\end{tabular}

a Porcentaje referido a la cal seca original.

${ }^{\text {b }}$ Para los análisis químicos se siguieron los métodos especificados en el Estándar Europeo EN-196.

c Pérdida por calcinación, indica el peso perdido debido a la calcinación a 975-1.000 ${ }^{\circ} \mathrm{C}$.

d Porcentaje conjunto de óxidos de Fe y Al.

* Desviación Estándar.

a Percentages related to original dry lime.

${ }^{b}$ The methods specified by the European Standard EN-196 were followed for the chemical analyses.

${ }^{c}$ Ignition loss, indicates the weight loss due to calcinations at $975-1,000{ }^{\circ} \mathrm{C}$.

' Percentage of $\mathrm{Fe}$ and $\mathrm{A} /$ oxides together.

* Standard Deviation.

con cera con el objeto de que la carbonatación tuviera lugar únicamente por las caras más largas. Las probetas fueron mantenidas en estas condiciones durante la evaluación de la variación del peso. Después de la carbonatación total de las muestras - establecida cuando el peso se mantiene constante, y confirmada por DRX como se advierte en los resultados de un trabajo previo (19) - se llevaron a cabo los análisis siguiendo la metodología descrita a continuación.

Se cortaron algunas probetas de $10 \times 10 \times 10 \mathrm{~mm}$ de las probetas prismáticas, con el fin de curarlas en una atmósfera de $\mathrm{CO}_{2}$ después de secarlas en una cámara con silicagel. Se aplicó vacío a las muestras con el objeto de eliminar el aire del sistema poroso. Después, la cámara se llenó con $\mathrm{CO}_{2}$ comercial $\left(100 \% \mathrm{CO}_{2}\right.$ a presión atmosférica), hasta que las muestras quedaron totalmente carbonatadas (8) (punto establecido cuando el peso de las muestras permanece constante en el tiempo).

\subsection{Metodología analítica}

\subsubsection{Estructura porosa}

La estructura porosa fue analizada de dos formas:

3.2.1.1. Porosidad abierta: la porosidad total es expresada como $\mathrm{P}$, en porcentaje, y es determinada de acuerdo a la prueba de saturación en agua (20) con una balanza hidrostática.

3.2.1.2. Distribución de tamaño de poro: calculada usando la porometría por intrusión de mercurio con un porosímetro de mercurio Micrometrics 9320 Poresizer, con registro automático de presión, de diámetro de poro, de volumen de intrusión y de área superficial de poro. surfaces were covered with wax so carbonation would proceed across the long sides only. The samples were stored and their weights monitored under these conditions throughout. The analyses described below were performed after carbonation had reached completion (defined to be when the weight remained constant, since the free portlandite is never entirely consumed (19)).

A number of specimens measuring $10 \times 10 \times 10 \mathrm{~mm}$ were cut out of the initial specimens and dried in a chamber with silica gel. $A$ vacuum was applied to remove the air from the pores in these specimens. They were then cured in a chamber filled with commercial $\mathrm{CO}_{2}\left(100 \% \mathrm{CO}_{2}\right.$ at atmospheric pressure) until the they were totally carbonated (8) (i.e., when they reached a constant weight).

\subsection{Analytical methodology}

\subsubsection{Pore structure}

The pore structure was analyzed in two ways:

3.2.1.1. Open porosity: total porosity or $P$, expressed in percentage, was determined by the water saturation test (20) using a hydrostatic scales.

3.2.1.2. Pore size distribution: calculated using a Micrometrics 9320 Poresizer mercury intrusion porosimeter that automatically records pressure, pore diameter, intrusion volume and pore surface area. 


\subsubsection{Contenido en agua}

Para evaluar el contenido en agua se empleó una cámara climática (CCI FCH-Xenolab). Las muestras fueron pesadas después de ser calentadas a $105^{\circ} \mathrm{C}$ y almacenadas en la cámara climática a $20{ }^{\circ} \mathrm{C}$ y a las diferentes humedades relativas $(0,20,30,40,50,60,70,80,90,95$ y $99 \%)$.

\section{RESULTADOS Y DISCUSIÓN}

\subsection{Estructura porosa}

En una investigación previa (18), se ha descrito la microestructura de pastas de cal con diferentes relaciones $A / C$, mediante diversas técnicas: absorción de agua, PIM (Porosimetría de Intrusión de Mercurio), MEB (Microscopía Electrónica de Barrido) y ADI (Análisis Digital de Imagen). Se sabe que la carbonatación modifica algunas características microestructurales: porosidad, porometría o superficie específica $(13,14,19,21,22)$. Para el propósito de esta investigación, se ha estudiado la estructura porosa en pastas de cal carbonatadas.

Estas pastas de cal pueden ser descritas como un conglomerado de cristales (18), luego se debe determinar el tamaño de partícula de la cal. Como se ha descrito por Cazalla et al. (23), el tamaño de poro también es función del tamaño de partícula: la cal almacenada bajo agua durante largos períodos de tiempo (proceso de envejecimiento) presenta una reducción del tamaño de partícula (de $0,85 \mu \mathrm{m}$ a $0,35 \mu \mathrm{m}$ después de 14 años), y consecuentemente origina un menor tamaño de poro en el mortero. Como muestra la Figura 1, la distribución de tamaño de partícula de la cal Ecobat ${ }^{\circledR}$ se encuentra entre $1 \mu \mathrm{m}$ y $11 \mu \mathrm{m}$, con un tamaño de partícula principal de $5 \mu \mathrm{m}$.

En la Figura 2, se observa que las pastas de cal presentan un tamaño de poro definido, cuyo diámetro de poro se incrementa con la relación $\mathrm{A} / \mathrm{C}$. El grado de hinchamiento de la estructura depende de la cantidad de agua de amasado empleada, incrementándose la porosidad cuando se incrementa la relación A/C (Tabla 2).

En la Figura 2, los resultados de la MIP muestran que el diámetro de poro en todas las pastas se encuentra entre $0,5 \mu \mathrm{m}$ y $5 \mu \mathrm{m}$, mientras el recorrido medio libre $(\lambda)$ para el aire es $0,066 \mu \mathrm{m}$ (a $760 \mathrm{~mm}$ de $\mathrm{Hg}$ y $20^{\circ} \mathrm{C}$ ). Por ello, en las pastas de cal tiene lugar la difusión de Fick (diámetro de poro $\geq 10 \lambda$, en este caso, diámetro de poro $\geq 0,66 \mu \mathrm{m}$ ). Así, pueden aplicarse ecuaciones lineales al estudio de las pastas de cal. En esta línea se debe apuntar que el tamaño de partícula puede influir en el tipo de difusión que tiene lugar: así, pastas con menor tamaño de partícula dan lugar a menores diámetros de poro, ocasionando una peor difusión.

\subsection{Contenido en agua}

Van Balen y Van Gemert (10) han afirmado que el contenido en agua es crítico en el proceso de

\subsubsection{Water content}

A (CCI FCH-Xenolab) climatic chamber was used to evaluate water content. The samples were weighed after heating to $105^{\circ} \mathrm{C}$ and stored in a climatic chamber at $20{ }^{\circ} \mathrm{C}$ and different relative humidities $(0,20,30,40$, $50,60,70,80,90,95$ and $99 \%)$.

\section{RESULTS AND DISCUSSION}

\subsection{Pore structure}

The microstructure of lime pastes with different $W / B$ ratios -found with a number of different techniques- was described in a previous paper (18). These techniques included water absorption, MIP (Mercury Intrusion Porosimetry), SEM (Scanning Electron Microscopy) and DIA (Digital Imaging Analysis). Carbonation is known to modify certain microstructural properties such as porosity or specific surface $(13,14,19,21,22)$. The pore structure of carbonated lime pastes was analyzed in the present study.

Since these lime pastes may be described to be a crystal conglomerate (18), lime particle size must be determined. Cazalla et al. (23) sustain that pore size also depends on particle size: lime stored in water for long periods of time (ageing process) exhibits a small particle size (from $0.85 \mu \mathrm{m}$ to $0.35 \mu \mathrm{m}$ after 14 years) and consequently generates smaller pore sizes in the mortar. As Figure 1 shows, Ecobat ${ }^{\circledR}$ lime particle size distribution ranged from 1 to $11 \mu \mathrm{m}$, with a main particle size of $5 \mu \mathrm{m}$.

Figure 2 shows that pore size was clearly defined in the lime pastes, with diameters increasing with the W/B ratio. The degree of structural swelling depended on the amount of mixing water used, while porosity also rose with the $W / B$ ratio (Table 2 ).

The MIP results given in Figure 2 indicate that in all the pastes pore diameter ranged from 0.5 to $5 \mu \mathrm{m}$, whereas the mean free path ( $\lambda$ ) was $0.066 \mathrm{~mm}$ (at $760 \mathrm{~mm}$ of $\mathrm{Hg}$ and $20^{\circ} \mathrm{C}$ ). Therefore, diffusion follows Fick's law in lime pastes (pore diameter $\geq 10 \lambda$; in this case, pore diameter $\geq 0.66 \mu \mathrm{m})$, which may $\bar{b}$ e analyzed with linear equations. In this vein, particle size may have a bearing on the type of diffusion: pastes with smaller particle sizes give rise to smaller pore diameters and hence to less fluid diffusion.

\subsection{Water content}

Van Balen and Van Gemert (10) sustained that water content is crucial to carbonation. A study of water content 


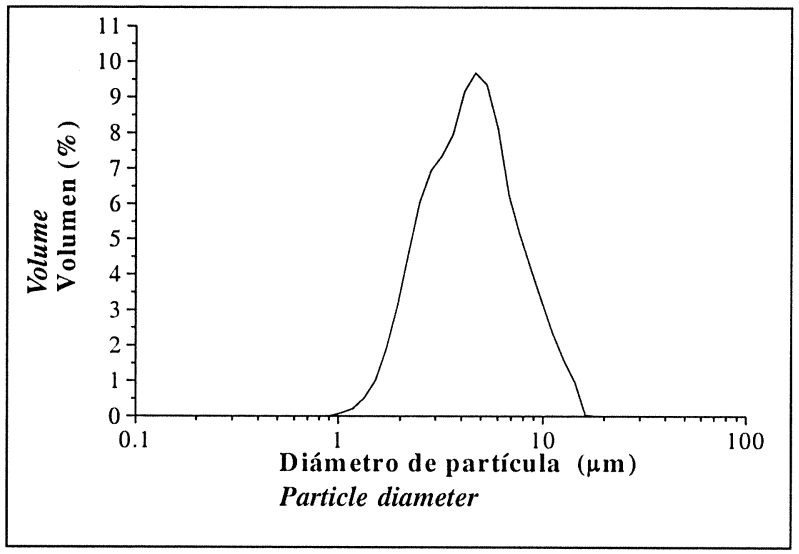

Figura.- Distribución del tamaño de partícula de la cal Ecobat. Figure 1.- Particle size distribution for Ecobat lime.

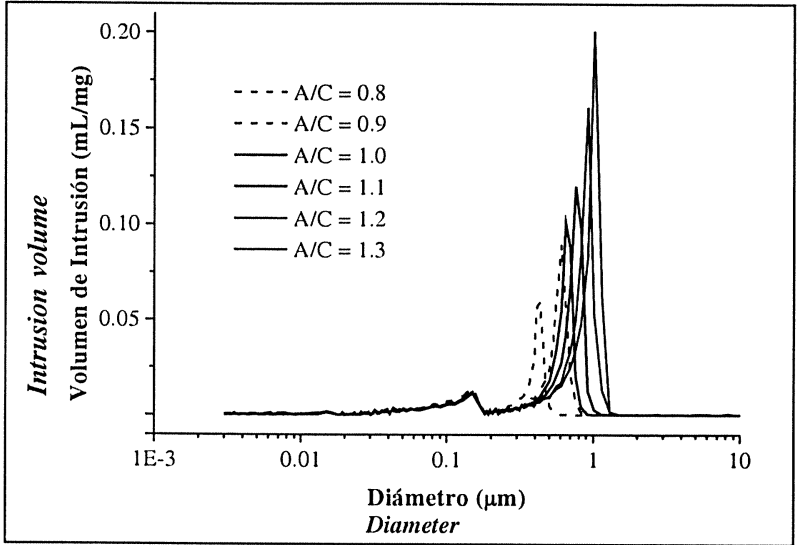

Figura 2.- Volumen de intrusión incremental vs. diámetro de poro para las seis pastas de cal.

Figure 2.- Increment volume intrusion vs. diameter of pore for the six lime pastes.

TABLA 2/ TABLE 2

Porosidad total para las diferentes pastas de cal Total porosity for the different lime pastes

\begin{tabular}{|c|c|c|c|c|c|c|}
\hline $\begin{array}{c}\text { Relación A/C } \\
\text { W/B Ratio }\end{array}$ & 0.8 & 0.9 & 1.0 & 1.1 & 1.2 & 1.3 \\
\hline $\mathrm{P}_{\mathrm{a}}(\%)$ & 51.8 & 56.8 & 56.7 & 60.1 & 62.4 & 62.6 \\
\hline D.E.* & 0.1 & 0.1 & 0.1 & 0.5 & 0.2 & 0.1 \\
\hline
\end{tabular}

* Desviación Estándar/Standard Deviation.

carbonatación. Por eso, un estudio del contenido en agua en estos materiales se revela esencial para la comprensión del fenómeno.

El contenido en agua de un material poroso (adsorbida en la superficie de los poros, o condensada por capilaridad) depende de la humedad relativa y de su microestructura $(24,25)$. La ecuación de Kelvin [7] describe el mayor radio de poro saturado de agua en función de la humedad relativa (26): in such materials is, therefore, essential to an understanding of this process.

Water content in a porous material (in the form of surface adsorption or capillary condensation) depends on relative humidity and material microstructure $(24,25)$. Kelvin's equation, eq. [7] gives the largest water-saturated pore radius for a given relative humidity (26):

$$
-\operatorname{Ln}\left(p / p_{s}\right)=2 \cdot \gamma \cdot V / R \cdot T \cdot r
$$

donde $\mathrm{p}$ es la presión de vapor de agua; $\mathrm{p}_{\mathrm{s}}$ es la presión de vapor de agua en atmósfera saturada; $\gamma$ es la energía superficial específica del agua; $V$ es el volumen molar del agua; $R$ es la constante de los gases; $T$ es la temperatura; y $r$ es el radio capilar.

A $20{ }^{\circ} \mathrm{C}$ y una humedad relativa de $60 \%$, condiciones a las cuales han sido curadas las probetas, sólo los poros menores de 0,002 $\mu \mathrm{m}$ (perteneciente a poros gel) pueden retener agua por capilaridad. Los resultados de la MIP muestran que no hay poros menores de $0,01 \mu \mathrm{m}$, por tanto, el agua es adsorbida en la superficie de los poros, mostrando todas las pastas el mismo contenido en agua de $0,4 \pm 0,02 \%$. Por tanto, la condensación capilar no tiene lugar en estas condiciones ambientales en pastas de cal, y la relación $A / C$ no tiene ninguna influencia en la where $p$ is water vapour pressure, $p_{s}$ water vapour pressure in a saturated atmosphere, $\gamma$ the specific surface energy for water, $V$ the molar volume of water, $R$ the universal. gas constant, $T$ temperature and $r$ the capillary radius.

At $20{ }^{\circ} \mathrm{C}$ and a relative humidity of $60 \%$, the curing conditions for the specimens, only pores under $0.002 \mu \mathrm{m}$ (gel pores) can hold water by capillarity. The MIP results showed that there were no pores under $0.01 \mu \mathrm{m}$; therefore, water was adsorbed on the pore surface. Moreover, all the pastes had the same water content, 0.4 $\pm 0.02 \%$. Capillary condensation does not take place in lime pastes, then, under these environmental conditions and the $W / B$ ratio has no effect on the amount of water retained. For a given type of lime, the water retained 
cantidad de agua retenida. Para una determinada cal, el agua retenida depende únicamente de la superficie de las partículas (i.e. tamaño de partícula). Por tanto, cales con menores tamaño de partícula tienen mayor área superficial, incrementando el contenido en agua y consecuentemente la velocidad de disolución de la portlandita en el proceso de carbonatación. Sin embargo, en estas cales tiene lugar una peor difusión como consecuencia de un menor diámetro de poro, desplazando el tipo de difusión hacia la difusión de Knudsen. Cuando la reacción es controlada por difusión, la velocidad de disolución del $\mathrm{Ca}(\mathrm{OH})_{2}$ no es importante.

Como muestra la Figura 3, el comportamiento higroscópico es similar para todas las pastas de cal carbonatadas, independientemente de su relación $\mathrm{A} / \mathrm{C}$. Para una humedad relativa de $99 \%$ la condensación capilar tiene lugar en poros con un diámetro $\leq 0,1 \mu \mathrm{m}$. Por tanto, prácticamente todo el contenido en agua es adsorbido sobre la superficie y prácticamente nada se condensa por capilaridad. A una HR de $99 \%$, el contenido en agua es de alrededor del $1 \%$.

Se puede establecer que la carbonatación no se ve muy afectada por la humedad relativa porque: i) no hay poros bloqueados a ninguna humedad relativa, de manera que se impida la difusión del aire a través de la estructura (siempre que no haya agua absorbida por capilaridad, o agua de lluvia); ii) la velocidad de disolución, que puede ser modificada por el contenido en agua, no es importante si el proceso es controlado por difusión. Sin embargo, una alta humedad relativa implica una gruesa capa de agua sobre la superficie de los poros que disminuye el tamaño de los mismos, dando lugar a una difusión ligeramente peor.

En el caso de morteros de cal, el proceso de la carbonatación se complica porque aparecen dos nuevos tipos de poros: los poros debidos al agregado y los poros de la ITZ (Zona de Transición Interfacial) entre el conglomerante y el agregado. Además, el comportamiento de la carbonatación puede cambiar por las modificaciones inherentes a la presencia del agregado.

\subsection{Velocidad del proceso de carbonatación}

Durante el proceso de curado de las pastas se registró el peso de las probetas frente al tiempo. La Figura 4 muestra como ejemplo estos datos para la pasta con una relación $\mathrm{A} / \mathrm{C}$ de 1,1 . En una primera etapa, se observa una disminución de peso debido a la pérdida de agua. Durante esta etapa de secado también tiene lugar el proceso de carbonatación, pero de una forma lenta hasta que la estructura permite la difusión del aire $(10,13)$. En el momento en que la carbonatación empieza a ser más importante que el proceso de secado, las probetas empiezan a aumentar su peso. En una segunda etapa, el peso se incrementa. En esta etapa, si el contenido en agua está en equilibrio con la humedad ambiente, el incremento de peso se debe exclusivamente a la carbonatación. Este incremento se advierte hasta que la carbonatación finaliza, momento a partir del cual el peso permanece constante. depends solely on particle surface area (i.e., particle size). Consequently, a smaller particle size determines a larger surface area and higher water content, which in turn signify a higher rate of portlandite dissolution during carbonation. Diffusion is less fluid in such types of lime, however, as a result of the smaller pore size, with Knudsen-type diffusion prevailing. When the reaction is controlled by diffusion, the rate of $\mathrm{Ca}(\mathrm{OH})_{2}$ dissolution is unimportant.

As Figure 3 shows, hygroscopic behaviour was similar for all the carbonated limes, irrespective of their W/B ratio. At a relative humidity of $99 \%$ capillary condensation took place in pores with a diameter $\leq 0.1 \mu \mathrm{m}$. Therefore, nearly all the water content was adsorbed on the surface and practically none condensed by capillarity. At $99 \%$ RH, water content was around $1 \%$.

Carbonation may be shown to be relatively unaffected by relative humidity because: i) there are no obstructed pores at any relative humidity that would prevent air from flowing through the structure (providing there is no water absorbed by capillarity or rain water); ii) the rate of dissolution, which may be affected by the water content, is unimportant if the process is controlled by diffusion Nonetheless, with high relative humidity a thick film of water forms on the pore surfaces, reducing pore size and slightly hindering diffusion.

Carbonation is more complex in lime mortar because two further types of pores are involved: aggregate-generated pores and ITZ (Interfacial Transition Zone) pores, located between the binder and the aggregate. Moreover, carbonation patterns may change due to modifications occasioned by the presence of the aggregate.

\subsection{Carbonation rate}

Specimen weight was recorded throughout the paste curing period. Figure 4 shows the data for the paste with a W/B ratio of 1.1 , by way of example. Initially, weight was observed to decline due to water loss. While carbonation also takes place during the drying period, it proceeds slowly until the air can flow through the structure $(10,13)$. When carbonation begins to prevail over drying, specimen weight starts to rise. In a second stage, weight increases. In this stage, if the water content is in equilibrium with the humidity in the air, the weight gain is due solely to carbonation. This rise continues until carbonation reaches an end, after which weight values remain flat. 


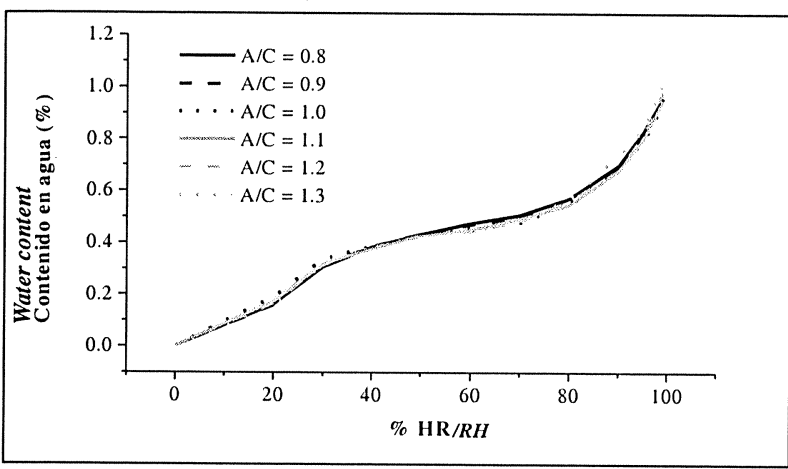

Figura 3.- Agua absorbida (\% en peso) vs. humedad relativa (\%) para las diferentes pastas de cal carbonatadas.

Figure 3.- Absorbed water (\% by weight) vs. relative humidity

(\%) for the different carbonated lime pastes.

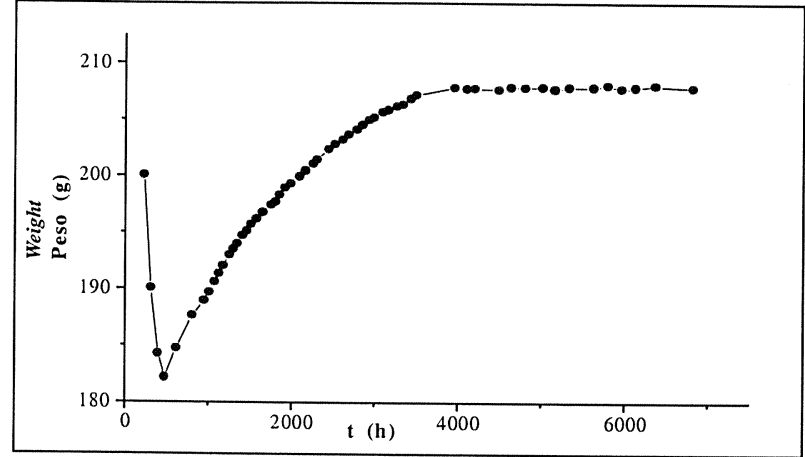

Figura 4.- Peso vs. tiempo para las probetas con una relación $\mathrm{A} / \mathrm{C}$ de 1,1 .

Figure 4.- Weight vs. time for the specimen with a W/B ratio of 1.1 .

TABLA 3/ TABLE 3

Tiempo de saturación y velocidad media del proceso de carbonatación para las pastas de cal Saturation time and average carbonation rate in lime pastes

\begin{tabular}{|c|c|c|c|}
\hline $\mathrm{A} / \mathrm{C}$ & $\begin{array}{c}\text { Tiempo de Saturación } \\
\text { Saturation Time } \\
(\mathrm{h})\end{array}$ & $\mathrm{Ca}(\mathrm{OH})_{2}(\mathrm{~g})$ & $\begin{array}{c}\text { Velocidad Media } \\
\text { Mean Rate } \\
(\mathrm{g} / \mathrm{h})\end{array}$ \\
\hline 0.8 & 5980 & 160 & 0.0269 \\
\hline 0.9 & 4820 & 147 & 0.0305 \\
\hline 1.0 & 4230 & 145 & 0.0342 \\
\hline 1.1 & 3760 & 131 & 0.0348 \\
\hline 1.2 & 3240 & 123 & 0.0380 \\
\hline 1.3 & 3050 & 114 & 0.0373 \\
\hline
\end{tabular}

\subsubsection{Tiempo de saturación y velocidad media de carbonatación}

El tiempo de saturación puede ser definido como el tiempo en el que las probetas alcanzan una carbonatación total, y el peso de las mismas permanece constante. Este período de tiempo incluye el proceso de secado y carbonatación. Como muestra la Tabla 3, el tiempo de saturación decrece según aumenta la relación $\mathrm{A} / \mathrm{C}$ comp consecuencia de ser un proceso controlado por difusión.

La Tabla 3 también muestra el peso inicial de $\mathrm{Ca}(\mathrm{OH})_{2}$, y la velocidad media de la carbonatación incluyendo los procesos de secado y carbonatación, al dividir el peso inicial de $\mathrm{Ca}(\mathrm{OH})_{2}$ entre el tiempo de saturación. La velocidad de carbonatación es más rápida para pastas con altas relaciones $A / C$, probablemente porque la microestructura de estas pastas permite un secado más rápido y una mejor difusión del aire debido a que presentan mayores diámetros de poro.

La Figura 5 muestra el peso de algunas probetas de $1 \times 1 \times 1 \mathrm{~cm}$ durante una carbonatación forzada en atmósfera de $\mathrm{CO}_{2}$. Todas las pastas saturan al mismo tiempo, independientemente de la relación $\mathrm{A} / \mathrm{C}$. En este caso de carbonatación forzada, el proceso no está controlado por la difusión sino por la reacción, siendo la disolución del $\mathrm{Ca}(\mathrm{OH})_{2}$ el proceso más lento. Sin embargo, como el tamaño de partícula (es decir, la superficie específica) es similar para todas las pastas, el tiempo de carbonatación es el mismo para las pastas con distinta relación $\mathrm{A} / \mathrm{C}$. Este comportamiento es claramente opuesto a la carbonatación natural y no forzada (Tabla 3), donde el tiempo de

\subsubsection{Saturation and mean carbonation rate}

Saturation time may be defined to be the time it takes specimens to reach total carbonation and a constant weight. This period includes both drying and carbonation. As Table 3 shows, saturation time declined as the W/B ratio rose because this process is controlled by diffusion.

Table 3 also gives the initial weight of $\mathrm{Ca}(\mathrm{OH})_{2}$ and the mean carbonation rate, including drying and carbonation times, found by dividing the initial weight of the $\mathrm{Ca}(\mathrm{OH})_{2}$ by saturation time. The carbonation rate was higher for pastes with high $W / B$ ratios, probably because the microstructure of these pastes, with large diameter pores, provides for speedier drying and greater air diffusion.

Figure 5 gives the weights of some of the $1 \times 1 \times 1 \mathrm{~cm}$ specimens during forced carbonation in a $\mathrm{CO}_{2}$-rich atmosphere. All the pastes reached saturation at the same time, regardless of their $W / B$ ratio. Forced carbonation is controlled not by diffusion but by the reaction, in which the dissolution of $\mathrm{Ca}(\mathrm{OH})_{2}$ is the slowest process. Nonetheless, since the particle size (i.e., specific surface) was similar in all the pastes, carbonation time was the same for pastes with different $W / B$ ratios. This behaviour is clearly distinguishable from what was observed in natural carbonation (Table 3), where saturation time depended 


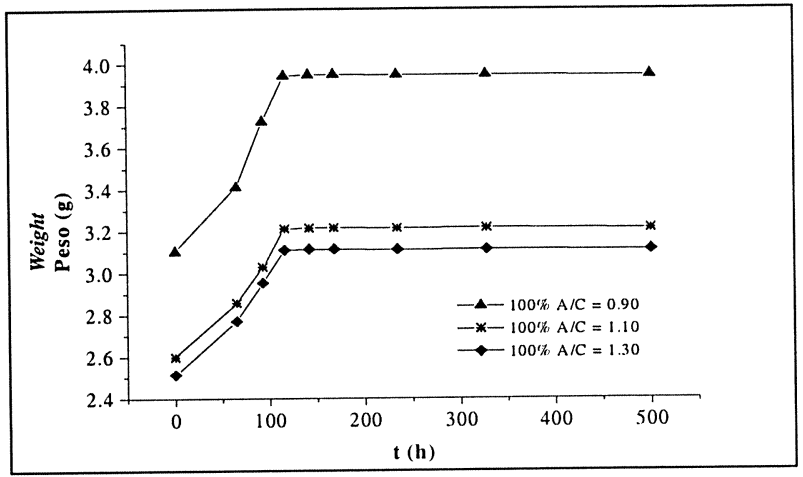

Figura 5.- Peso de las diferentes probetas vs. tiempo, durante una carbonatación forzada.

Figure 5. - Weight of the different specimens vs. time, with forced carbonation.

saturación depende de la relación A/C. Por lo tanto, la carbonatación no forzada (o natural) es un proceso controlado por difusión, donde tiene lugar la difusión de Fick (11).

\subsubsection{Variación del peso frente al tiempo}

El curado de las probetas se ha llevado a cabo intentando simular el comportamiento en obra, incluyendo el secado y la carbonatación. Durante un período de tiempo al comienzo del curado, la variación de peso, desde que éste empieza a incrementarse, es debido a un solapamiento de dos procesos: la carbonatación y el secado. Para estudiar exclusivamente el proceso de carbonatación, solamente se ha tenido en cuenta la reacción del $\mathrm{CO}_{2}$ con la última mitad del hidróxido de calcio, etapa en la cual puede asumirse razonablemente que el proceso de secado ha finalizado.

Como muestra la Figura 6, el proceso de carbonatación de la segunda mitad del hidróxido de calcio presenta un comportamiento similar para las seis pastas de cal. $X$ representa en la Figura el tiempo de carbonatación de la primera mitad de $\mathrm{Ca}(\mathrm{OH})_{2}$, que es diferente para cada relación $\mathrm{A} / \mathrm{C}$. Las curvas han sido desplazadas para unificar el inicio de la carbonatación de la segunda mitad de $\mathrm{Ca}(\mathrm{OH})$, a tiempo 0 (seleccionado arbitrariamente), y facilitar la comparación.

El resultado para cada pasta es la media del comportamiento de cuatro probetas. El peso de las pastas con altas relaciones $\mathrm{A} / \mathrm{C}$ empieza a ser constante en menos tiempo y con menores incrementos de peso, como era de esperar por su mayor tamaño de poro. Representando los valores de peso frente a $t^{1 / 2}$, como indica la ecuación [8], se obtienen líneas rectas para cada una de las seis pastas, cuyas pendientes son el parámetro $\mathrm{A}$ :

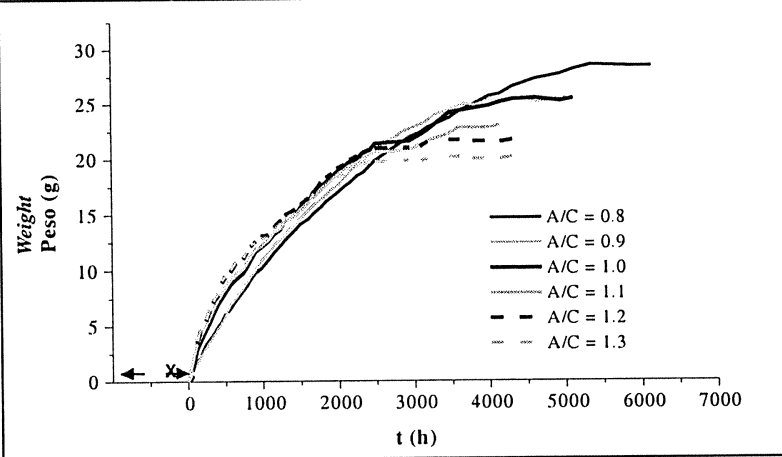

Figura 6.- Peso ganado vs. tiempo de carbonatación de la segunda mitad de $\mathrm{Ca}(\mathrm{OH})_{2}$ para las seis pastas de cal. $X$ representa el tiempo de carbonatación de la primera mitad de $\mathrm{Ca}(\mathrm{OH})_{2}$, siendo diferente para cada relación A/C. Las curvas han sido desplazadas para unificar el inicio de la carbonatación de la segunda mitad de $\mathrm{Ca}(\mathrm{OH})_{2}$ a tiempo 0 (seleccionado arbitrariamente).

Figure 6.- Weigh gained vs. time in the carbonation of the second half of $\mathrm{Ca}(\mathrm{OH})$, for the six lime pastes. $X$ represent the carbonation time of the first half of $\mathrm{Ca}(\mathrm{OH})_{2}$, being different for each W/B ratio. The curves have been shifted to standardize at time 0 (arbitrarily selected) the begin of the carbonation of the second half of $\mathrm{Ca}(\mathrm{OH})_{2}$,

on the $W / B$ ratio. In conclusion, when Fick's law prevails, unforced (natural) carbonation is controlled by diffusion (11).

\subsubsection{Variation in weight versus time}

Specimens were cured under conditions that simulated worksite conditions, including drying and carbonation. The initial weight increases during early curing are due to the overlapping of two processes: carbonation and drying. In order to study carbonation alone, the analysis was based on the $\mathrm{CO}_{2}$ reaction with the last half of the calcium hydroxide only, since the drying process can reasonably be assumed to have reached completion by that stage.

As Figure 6 shows, carbonation of the second half of the calcium hydroxide was similar in all six lime pastes. In the figure, $X$ represents the carbonation time of the first half of the $\mathrm{Ca}(\mathrm{OH})_{2}$, which varied for each $W / B$ ratio. The curves were shifted to establish a standardized start-up time $(=0)$ for the second half of $\mathrm{Ca}(\mathrm{OH})_{2}$ carbonation for readier comparison.

The value shown for each paste is the mean of the observations for four specimens. The weight of pastes with high $W / B$ ratios began to plateau sooner and with smaller weight increases, as expected, given their larger pore size. Plotting weight against $t^{1 / 2}$, as in equation [8], yielded straight lines for all six pastes, whose slopes are parameter $A$ : 
TABLA 4/ TABLE 4

Parámetros cinéticos para las pastas de cal Lime pastes kinetic parameters

\begin{tabular}{|c|c|c|c|c|c|c|}
\hline $\begin{array}{c}\text { relación A/C } \\
\text { W/B ratio }\end{array}$ & 0.8 & 0.9 & 1.0 & 1.1 & 1.2 & 1.3 \\
\hline $\begin{array}{c}\mathrm{A} \\
\left(\mathrm{g} / \mathrm{cm}^{2} \cdot \mathrm{h}^{1 / 2}\right)\end{array}$ & 0.00344 & 0.00346 & 0.00350 & 0.00360 & 0.00368 & 0.00365 \\
\hline $\mathrm{k}$ & 0.22 & 0.22 & 0.22 & 0.22 & 0.22 & 0.22 \\
\hline$\rho\left(\mathrm{g} / \mathrm{cm}^{3}\right)$ & 1.15 & 1.04 & 1.03 & 0.97 & 0.92 & 0.89 \\
\hline $\begin{array}{c}\text { Área de la probeta } \\
\text { Specimen area } \\
\left(\mathrm{cm}^{2}\right)^{*}\end{array}$ & 14 & 14 & 14 & 13.5 & 13.2 & 12.8 \\
\hline $\begin{array}{c}\text { Perimetro de la } \\
\text { probeta } \\
\text { Specimen perimeter } \\
\left(\mathrm{cm}^{*}\right.\end{array}$ & 13.47 & 13.47 & 13.47 & 13.29 & 13.11 & 12.93 \\
\hline $\begin{array}{c}\mathrm{B}_{\mathrm{A}}^{* *} \\
\left(\mathrm{~cm}^{-1 / 2}\right)\end{array}$ & 0.0136 & 0.0150 & 0.0153 & 0.0170 & 0.0182 & 0.0186 \\
\hline $\begin{array}{c}\mathrm{B}^{* * *} \\
\left(\mathrm{~cm}^{-1 / 2}\right)\end{array}$ & 0.0134 & 0.0150 & 0.0160 & 0.0166 & 0.0183 & 0.0186 \\
\hline
\end{tabular}

* Ambos valores se obtuvieron considerando la retracción de las probetas.

** Calculados de los valores de A.

*** Calculados de la ecuación [9].

* Provision made for specimen shrinkage.

* Calculated from $A$ values.

*** Calculated from equation [9].

donde $W$ es el peso ganado por unidad de área $\left(\mathrm{g} / \mathrm{cm}^{2}\right)$, A es el nuevo parámetro $\left(\mathrm{g} / \mathrm{cm}^{2} \cdot \mathrm{s}^{1 / 2}\right)$ y $\mathrm{t}$ es el tiempo. Como resume la Tabla 4, el parámetro A es casi similar para las diferentes pastas de cal, incrementándose ligeramente con la relación $\mathrm{A} / \mathrm{C}$ (menos de un $6 \%$ ), debido al incremento en el diámetro de poro, que permite una mejor difusión del aire a través de la estructura (Figura 2). Así, este ligero incremento del parámetro A es consecuencia del empleo de diferente cantidad de agua de amasado.

\subsubsection{Frente de carbonatación}

Se acepta generalmente (10), que la ecuación [9], derivada de la difusión de Fick, describe el movimiento del frente de carbonatación:

$$
x=B \sqrt{t}
$$

donde $x$ es la profundidad de carbonatación (cm), B es otro parámetro $\left(\mathrm{cm} / \mathrm{s}^{1 / 2}\right)$ y t es el tiempo. El mismo estudio puede ser llevado a cabo entendiendo x como el área carbonatada $\left(\mathrm{cm}^{2}\right)$ por el perímetro a través del cual tiene lugar la carbonatación (cm).

De esta forma, el estudio puede ser aplicado a probetas que carbonatan por varias caras, pero todas ellas paralelas a un eje perpendicular al plano de carbonatación de estudio. El estudio del frente de carbonatación a través de una cara es un caso particular de este estudio general, que presenta la ventaja de no estar influenciado por las discontinuidades del frente de carbonatación observadas con el método de la fenolftaleína. Dados el área carbonatada (teniendo en cuenta la retracción de la probeta) where $W$ is the weight gain per unit of area $\left(\mathrm{g} / \mathrm{cm}^{2}\right), A$ is a new parameter $\left(\mathrm{g} / \mathrm{cm}^{2} \cdot \mathrm{s}^{1 / 2}\right)$ and $t$ is time. As the summary in Table 4 shows, parameter $A$ was more or less similar for the different lime pastes, rising slightly with the $W / B$ ratio (by less than 6\%), for the concomitant larger pore size provides for better air diffusion through the structure (Figure 2). Hence, this slight rise in parameter $A$ was due to the use of different amounts of mixing water.

\subsubsection{Carbonation front}

Equation [9], derived from Fick's law, is generally assumed (10) to describe the increasing depth of the carbonation front:

[9]

where $x$ is the carbonation depth (cm), B is a constant $\left(\mathrm{cm} / \mathrm{s}^{1 / 2}\right)$ and tis time. The same analysis can be performed assuming $x$ to be the carbonated area $\left(\mathrm{cm}^{2}\right)$ times the carbonation perimeter $(\mathrm{cm})$.

Consequently, this approach can be used to analyze specimens carbonating on several surfaces, all parallel to a line perpendicular to the carbonation plane under study. The advantage to analyzing the carbonation front along only one side, a specific case of this general approach, is that it is unaffected by the carbonation front discontinuities observed in the phenolphthalein method. Parameter $B$ is found by dividing the 
cuyos valores se presentan y el perímetro a través del cual carbonata la probeta y el tiempo de carbonatación, puede calcularse el parámetro B (Tabla 4). Este parámetro se determina dividiendo el área carbonatada entre el perímetro de carbonatación (para conocer el frente de carbonatación), y, a su vez, a partir de la ecuación [9], ese cociente se divide entre $t^{1 / 2}$ (tiempo de carbonatación de la probeta).

En la Tabla 4 se puede observar cómo el parámetro $B$ se incrementa con la relación $A / C$ de una forma proporcional (con un coeficiente de correlación de 0,99). Una mayor cantidad de cal por unidad de volumen (que origina variación de la compactación, y, por tanto, de la densidad) causa una menor velocidad del frente de carbonatación.

\subsubsection{Relación entre los parámetros A y B}

Estos dos parámetros $A$ y $B$, pueden ser relacionados a través de la ecuación [10] propuesta:

$$
B_{\Lambda}=\frac{A}{\kappa \cdot \rho}
$$

donde, $\mathrm{k}$ [g (ganados debido a la carbonatación)/g (material)] y $\rho\left(\mathrm{g} / \mathrm{cm}^{3}\right)$ son constantes del material. La constante $k$ depende del tipo de material (cemento, cal, etc.), y más exactamente de la cantidad de compuestos susceptibles de ser carbonatados $\left(\mathrm{Ca}(\mathrm{OH})_{2}, \mathrm{Mg}(\mathrm{OH})_{2}\right.$, etc.) por gramo de material. $\rho$ es definido como la compactación del material. Ambas constantes, ky $\rho$, pueden ser fundidas en una constante [g (ganados debido a la carbonatación) $/ \mathrm{cm}^{3}$ (material)]. Por tanto, a través de la ecuación [10], el parámetro $B$ puede calcularse a partir del parámetro $A$.

El parámetro B puede ser calculado de dos formas: i) con la ecuación [9], midiendo el área carbonatada según se ha explicado, se obtiene el parámetro $B$, que describe todo el proceso natural de una probeta (procesos de carbonatación y secado); ii) con los valores de A (calculados a partir de la segunda mitad del hidróxido de calcio), se obtiene el parámetro $\mathrm{B}_{\mathrm{A}^{\prime}}$ que describe solamente el proceso de carbonatación.

Hā; una gran similitud entre los parámetros $B$ y $B_{A}$ (Tabla 4). Este hecho indica que no hay diferencia entre el proceso estudiado exclusivamente como carbonatación y el proceso que incluye el secado y la carbonatación.

Se podría pensar que el proceso de secado retrasa la velocidad de carbonatación debido al bloqueo de los poros: sin embargo, este estudio demuestra lo contrario. Este hecho puede ser explicado porque el proceso de secado tiene lugar desde la cara externa hacia el centro de la probeta, justo la misma dirección que el proceso de carbonatación. Además, el proceso de secado es generalmente más rápido que el proceso de carbonatación, por tanto cuando el proceso de la carbonatación alcanza una cierta profundidad en la probeta, la estructura ya está seca a esa profundidad. Así, la influencia del proceso de carbonated area (making provision for specimen shrinkage), whose values are shown (Table 4), by the carbonation perimeter (to determine the carbonation front) and, pursuant to equation [9], that quotient is in turn divided by $t^{1 / 2}$ (specimen carbonation time).

Table 4 shows how parameter B grows proportionally with the $W / B$ ratio (with a correlation coefficient of 0.99). A greater amount of lime per unit of volume (which causes variations in consolidation and therefore density) reduces the carbonation front penetration rate.

\subsubsection{Relationship between parameters $A$ and $B$}

Parameters $A$ and $B$ can be related as in proposed equation [10]:

where $k$ [g (carbonation gain/ $g$ (material)] and $\rho(g /$ $\mathrm{cm}^{3}$ ) are material constants. Constant $k$ depends on the type of material (cement, lime or similar) and more precisely on the amount of compounds liable to be carbonated $\left(\mathrm{Ca}(\mathrm{OH})_{2} \mathrm{Mg}(\mathrm{OH})_{2}\right.$ and the like) per gram of material. The other constant, $\rho$, is a measure of material consolidation. These two terms, $k$ and $\rho$, can be merged into a single constant [g (carbonation gain)/ $\mathrm{cm}^{3}$ (material)]. Consequently, using equation [10], parameter $B$ can be calculated from parameter $A$.

Parameter B can be calculated in two ways: i) solving for eq. [9] and measuring the carbonated area as explained yields parameter $B$, which describes the entire natural process taking place in a specimen (carbonation and drying); ii) the values of $A$ (calculated from the second half of the calcium hydroxide) yield parameter $B_{\alpha}$ which describes the carbonation process only.

The close similarity between parameters $B$ and $B_{A}$ (Table 4) is an indication that there is no difference between the process studied as carbonation only and the process that includes both drying and carbonation.

Although drying might be thought to retard the carbonation rate due to pore obstruction, this study provides evidence for the contrary. This may be explained by the fact that both carbonation and drying take place from the outside in on the specimen. Moreover, since drying is usually a speedier process than carbonation, the depth at which 
secado sobre la velocidad de carbonatación puede ser considerada como despreciable, al menos en las pastas de cal.

Dado que la carbonatación de los morteros es un proceso controlado por difusión, se puede destacar que todos los cambios en las condiciones ambientales que creen una mejor difusión del $\mathrm{CO}_{2}$ a través del sistema acelerarán la reacción hasta que otro proceso se haga más lento $y$, por tanto, pase a ser el factor limitante de la velocidad del proceso (por ejemplo, la disolución del $\mathrm{Ca}(\mathrm{OH})_{2}$ en una atmósfera de $\mathrm{CO}_{2}$ ).

\section{CONCLUSIONES}

1- El agua contenida en las pastas de cal se encuentra exclusivamente adsorbida sobre la superficie de los poros y no condensada por capilaridad. No hay diferencia en el contenido en agua entre pastas con diferente relación A/C. Por tanto, el contenido en agua está sólo en función de la humedad relativa y del tamaño de partícula.

2- Se ha definido un nuevo parámetro $A$, como gramos de masa ganados debidos a la carbonatación por área y tiempo ${ }^{1 / 2}$. Este parámetro varía ligeramente con la relación $A / C$, como consecuencia de la modificación que tiene lugar en la microestructura de las pastas de cal cuando cambia la relación A/C. Por tanto, en todas las pastas de cal tiene lugar la difusión de Fick, cambiando la cantidad de $\mathrm{CO}_{2}$ que difunde y reacciona en función del diámetro de poro que se incrementa ligeramente en las pastas con mayores relaciones $\mathrm{A} / \mathrm{C}$.

3- En las pastas de cal, el parámetro B (referido al avance del frente de carbonatación) se incrementa de una forma proporcional al incremento de la relación A/C como consecuencia de una disminución de la compactación del material.

4- Ambos parámetros, $A$ y $B$, se pueden relacionar a través de una expresión que incluye dos constantes: $k$ que es característica de la composición del material y $\rho$ que representa la compactación del material. El parámetro $B_{A}$ obtenido con el parámetro $A$ conduce al mismo valor que $B$, calculado con el frente de carbonatación, indicando que el proceso de secado no retrasa el proceso de carbonatación en las pastas de cal.

\section{AGRADECIMIENTOS}

El presente estudio ha sido financiado por el Ministerio de Ciencia y Tecnología, Plan Nacional de Investigación, Programa de Desarrollo e Innovación Tecnológica (I+D+I), Proyecto MAT2000-1347. carbonation takes place is normally already dry. Therefore, in lime pastes at least, the effect of drying on the carbonation rate may be regarded to be negligible.

Inasmuch as mortar carbonation is controlled by diffusion, any change in environmental conditions that enhances $\mathrm{CO}_{2}$ diffusion through the system will hasten the reaction until some other process slackens and becomes the limiting factor in the carbonation rate (the dissolution of $\mathrm{Ca}(\mathrm{OH})_{2}$ in a $\mathrm{CO}_{2}$-rich atmosphere, for instance).

\section{CONCLUSIONS}

1- The water in lime pastes is found solely in the form of surface adsorption, with no capillary condensation detected. There is no difference in the water content between pastes with different $W / B$ ratios. Therefore, the water content depends only on relative humidity and particle size.

\section{2- $A$, a new parameter, has been defined, whose unit is grams of carbonation gain, multiplied by area and time ${ }^{1 / 2}$. This parameter varies slightly with the $W / B$ ratio as a result of the changes taking place in lime paste microstructure with variations in the $W / B$ ratio. Fick's diffusion takes place in all the lime pastes, and the amount of $\mathrm{CO}_{2}$ flowing through the specimen and reacting with its components changes with pore diameter, which is slightly larger in pastes with higher $W / B$ ratios.}

3- In lime pastes, parameter $B$ (an indication of the increase in carbonation front depth) grows in proportion to the rise in the $W / B$ ratio, which lowers paste consolidation.

4- Parameters $A$ and $B$ can be related through an expression that includes two constants: $k$, which is characteristic of material composition, and $\rho$, which represents the degree of consolidation. The similarity between the values of parameter $B_{A}$ obtained from parameter $A$, and $B$, calculated from the carbonation front, is an indication that drying does not retard carbonation in lime pastes.

\section{ACKNOWLEDGEMENTS}

This study was funded by the Ministry of Science and Technology, National Research Plan, Development and Technological Innovation (R\&D+i) programme, Project MAT 2000-1347.

\section{BIBLIOGRAFÍA}

(1) A. Steffens, D. Dinkler, H. Ahrens, «Modelling carbonation for corrosion rick prediction of concrete structures», Cem. Concr. Res., 32 (2002), pp. 935-941.

(2) M. A. Sanjuán, C. del Olmo, «Carbonation resistance of one industrial mortar used as a concrete coating», Build. Environ., 36 (2001), pp. 949-953. 
(3) Y. LO, H. M. Lee, «Curing effects on carbonation of concrete using a phenolphthalein indicator and Fourier-transform infrared spectroscopy», Build. Environ., 37 (2002), pp. 507-514.

(4) C. Rodríquez-Navarro, O. Cazalla, «Liesegang pattern development in carbonation traditional lime mortars», Proc. R. Soc. Lond., 458 (2002), pp. 2261-2273.

(5) Y. F. Houst, F. H. Wittmann, «Influence of porosity and water content on the diffusivity of $\mathrm{CO}_{2}$ through hydrated cement paste», Cem. Cocr. Res., 32 (2002), pp. 1923-1930.

(6) R. M. Dheilly, J. Tudo, M. Quéneudec, «Influence of climatic conditions on the carbonation of quicklime», JMEPEG, 7 (1998), pp.

(7) S. Shih, C. Ho, Y. Song, J. Lin, «Kinetics of the reaction of $\mathrm{Ca}(\mathrm{OH})_{2}$ with $\mathrm{CO}_{2}$ at low temperature», Ind. Eng. Chem. Res., 38 (1999), pp. 1316-1322.

(8) R. M. Dheilly, J. Tudo, Y. Sebai Bi, M. Quéneudec, «Influence of storage conditions on the carbonation of powdered $\mathrm{Ca}(\mathrm{OH}) 2$ » Construction and Building Materials, 16 (2002), pp. 155-161.

(9) K. Van Balen, «Carbonation reaction of lime, kinetic at ambient temperature», Cem. Concr. Res., 35 (2004), pp. 647-657.

(10) K Van Balen, D. Van Gemert, «Modelling lime mortar carbonation», Mater. Struct., 27 (1994), pp. 393-398.

(11) N. M. Zouridakis, I. G. Economou, K. P. Tzevelekos, E. S. Kikkinides, «Investigation of the physicochemical characteristics of ancient mortars by static and dynamic studies», Cem. Concr. Res., 30 (2000), pp. 1151-1155.

(12) S. Sánchez-Moral, J. García-Guinea, L. Luque, R. González-Martín, P. López-Arce, «Cinética de carbonatación de morteros experimentales de cal de tipo romano», Mater. Construcc., vol. 54, no 275 (2004), pp. 23-37.

(13) J. Lanas, J. I. Alvarez, «Masonry repair lime-based mortars: Factors affecting the mechanical behaviour», Cem. Concr. Res., 33

(2003), pp. 1867-1876.
(14) B. Johannesson, P. Utgenannt, «Microstructural changes caused by carbonation of cement mortar», Cem. Concr. Res., 31 (2001), pp. 925-931.

(15) Y. F. Houst, F. H. Wittmann, «Dept profiles of carbonates formed during natural carbonation», Cem. Concr. Res., 24 (1994), pp. $1165-1176$.

(16) M. Sahimi, Applications of percolation theory, Ed. Taylor \& Francis, 1994.

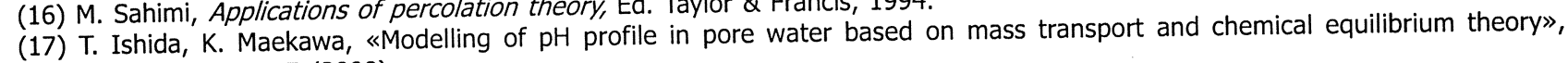
Proceeding of JSCE., 47 (2000).

(18) M. Arandigoyen, J. L. Pérez Bernal, M. A. Bello López, J. I. Álvarez, «Lime pastes with different kneading water: pore structure and capillary porosity», Appl. Surf. Sci., 252(5) (2005), pp. 1449-1459.

and capillary porosity», Appl. Surf. SCl., $252(5)(2005)$, pp. 1449-1459.
(19) M. Arandigoyen, J. I. Alvarez, «Blended pastes of cement and lime: Pore structure and capillary porosity», Appl. Surf. Sci., In Press, Corrected Proof, Available online 11 November 2005.

(20) RILEM, Mater. Struct., 13 (1980), pp. 175-253.
(21) V. T. Ngala, C. L. Page, «Effects of carbonation on pore structure and diffusional properties on hydrated cement pastes», Cem. Concr. Res., 27 (7) (1997), pp. 995-1007.

(22) W. P. S. Días, «Reduction of concrete sorptivity with age through carbonation», Cem. Concr. Res., 30 (2000), pp. 1255-1261. (23) O. Cazalla, C. Rodríguez-Navarro, «Ageing of lime putty: Effect on traditional lime mortar carbonation», J. Am. Ceram. Soc., 83 (2000), pp. 1070-1076.

(24) M. B. Weimann, V. C. Li, «Hydral behaviour of engineered cementitious composites (ECC)», Restoration of Building and Monuments,

9 (5) (2003), pp. 513-534.
(25) A. Stazi, M. D'Orazio, E. Quagliarini, «In-life prediction of hydrometric behaviour of building materials: an

(25) A. Stazi, M. D'Orazio, E. Quagliarini, «In-life prediction of hydrometric behaviour 37 (2002), pp. 733-739.
geometry to the determination of adsorption and suction properties», Build. Environ., 32004$)$, pp. 75-79.
(26) S. Chatterji, «An explanation for the unsaturated state of water stored concrete», Cem. Concr. Comp., 26 (20) 